\title{
Prevalence, Treatment and Control of Hypertension in a Croatian Endemic Nephropathy Area
}

\author{
Živka Dika ${ }^{a} \quad$ Josip Juras ${ }^{b} \quad$ Jelena Kos ${ }^{a}$ Karen Edwards $^{f}$ Margareta Fištrek $^{a}$ \\ Vedran Premužića Mario Laganovića Mirta Abramović-Baríc ${ }^{c}$ Ante Cvitkovićd \\ Ivana Vuković Lela ${ }^{a}$ Sandra Karanovića Dragana Jurićd ${ }^{\circ}$ Milan Bitunjac ${ }^{\mathrm{e}}$ \\ Tomislav Teskera ${ }^{\mathrm{e}}$ Bojan Jelakovića \\ ${ }^{a}$ Division of Nephrology, Arterial Hypertension Dialysis and Transplantation, Department of Internal Medicine, \\ University Hospital Center Zagreb, School of Medicine, University of Zagreb, ${ }^{b}$ University Hospital Center Zagreb, \\ School of Medicine, University of Zagreb, Zagreb, ' Outpatient Clinic Bebrina, Bebrina, ${ }^{d}$ Institute for Public Health \\ Brodsko-Posavska County, and ${ }^{e}$ Dr. Josip Benčević General Hospital, Slavonski Brod, Croatia; ${ }^{f}$ Department of \\ Epidemiology, University of Washington, Seattle, Wash., USA
}

\section{Key Words}

Endemic nephropathy - Arterial hypertension - Prevalence • Treatment $\cdot$ Control

\begin{abstract}
Background: Hypertension is not considered to be a characteristic of endemic nephropathy (EN). Recent observations suggested that it might be more prevalent than it was reported before. Aim: The aim of our study was to analyze prevalence, treatment and control of hypertension in a Croatian endemic area. Methods: In the present cross-sectional study, 1,602 farmers were enrolled, 1,246 from EN and 356 from control villages. Epidemiological and medical histories were taken and clinical and laboratory examinations performed for kidney function. Blood pressure was measured following the ESH/ESC guidelines. Results: The prevalence of hypertension in EN villages was higher than in control ( 50.8 vs. $46.5 \%, p=0.005$ ). There was no difference in overall treatment, control of all and treated hypertensives between
\end{abstract}

the villages. In all villages, women were treated more than men (EN 41.6 vs. 28.4\%, p < 0.001; control 46.4 vs. $27.3 \%$, p < 0.001 ), but better control of treated was achieved in men (EN 24.7 vs. $17.4 \%, p=0.002$; control 29.6 vs. $15.5 \%, p=0.002$ ). Women had lower income and level of education than men ( $p<0.01)$. Conclusion: Hypertension is highly prevalent in endemic villages. In all villages, men had better blood pressure control despite being treated less. This finding could be explained by poorer education and income in women.

Copyright $\odot 2012$ S. Karger AG, Basel

\section{Introduction}

Endemic nephropathy (EN) is a chronic tubulointerstitial disease affecting farmers living in rural areas of Bosnia and Herzegovina, Bulgaria, Croatia, Romania, and Serbia along the Danube river basin [1-6]. According to the recent data, prevalence of confirmed EN cases in majority of endemic areas is approximately 2-5\%, and

\section{KARGER}

Fax +4161306 1234 E-Mail karger@karger.ch www.karger.com (c) 2012 S. Karger AG, Basel

$1420-4096 / 12 / 0356-0678 \$ 38.00 / 0$

Accessible online at: www.karger.com/kbr
Bojan Jelaković, $\mathrm{MD}, \mathrm{PhD}$

School of Medicine, University of Zagreb

Division of Nephrology, Arterial Hypertension and Dialysis

University Hospital Center Zagreb, Kišpatićeva 12, HR-10000 Zagreb (Croatia)

Tel. +385 12388 271, E-Mail jelakovicbojan@gmail.com 
those suspected of having EN 8-10\% [2, 5-11]. In the last few decades, a shift to older ages has been observed in both groups $[2,5,6,9,12,13]$. Epidemiologic studies conducted in the aforementioned countries revealed unique epidemiologic features of EN that include the following: focal occurrence within certain villages leaving the nearby ones spared; restriction to rural farming populations; a familiar but not inherited pattern of the disease often affecting several members of the same household; occurrence in adults and never in children under 15 years of age and strong association with upper urinary tract transitional cell carcinoma $[1-6,8,10]$.

The hallmark of the early phase of EN is proximal tubule damage, a process which starts from the outer cortex spreading gradually to the inner parts leaving glomeruli spared for a long period during the clinical course of the disease [14]. EN is a slowly progressing nephropathy with insidious onset, and hypertension was not reported to be a characteristic of the early phase and appeared only when accompanying advanced stages of chronic kidney disease $[1,3,13]$. Later occurrence of hypertension was usually explained by tubulopathy, i.e. salt wasting nephropathy and probably with the destruction of macula densa in the early phase of the disease [14-16]. Nowadays, EN is considered to be an environmental form of aristolochic acid nephropathy, a disease which was firstly described in Belgium and after that worldwide [15-23]. Recent studies have shown that chronic ingestion of aristolochic acid which derived from the seeds of a weed, Aristolochia clematitis (Birthwort) that comingled with wheat grain in cultivated fields during harvest in EN villages resulted in the contamination of wheat flour used for preparing home-baked bread [21]. Moreover, aristolochic acid DNA adducts known as the fingerprint of aristolochic acid exposure were detected in kidney and tumor tissue of these EN patients [17, 18]. Besides histopathological similarities and frequently present upper urothelial cancers, both EN and iatrogenically induced aristolochic acid nephropathy share the same clinical characteristics, with late onset of hypertension being one of them $[17,23]$.

Although EN has been investigated for more than 50 years, searching PubMed we failed to find any comprehensive study on the prevalence of hypertension and the characteristics of hypertensives in this particular rural area. Moreover, there have been no reports on the treatment and the control of hypertension in endemic villages, and therefore our aim was to investigate characteristics of hypertension in a Croatian rural endemic area.

Hypertension in an Endemic Nephropathy Area

\section{Methods and Subjects}

\section{Subjects}

Out of 1,728 adult inhabitants (693 men and 1,035 women) who were enrolled in the present cross-sectional study conducted between 2005 and 2008 in six EN (Banovci, Bebrina, Kaniža, Pričac, Slavonski Kobaš, Živike) and two non-EN control villages (Donja Bebrina, Klakar), 1,602 inhabitants were considered eligible for further analyses (fig. 1). All inhabitants older than 18 years of age in both endemic and control villages were invited to participate and were examined on a door-to-door basis. Pregnant women, patients with terminal illness who were bed-ridden, patients with severe disability or those who have had at least one limb amputated or immobilized and mentally ill or suffering from dementia were considered ineligible to enter the study protocol. Forty-three diabetic patients together with 4 non-diabetic patients with nephrotic proteinuria were excluded from further study.

After an epidemiological questionnaire, medical history taking, and clinical and laboratory examinations, the EN population was classified according to the modified WHO criteria $[11,24]$ as 'diseased', 'suspected of having EN', 'at risk for EN', and 'others'. Criteria we used were: (a) positive family (household) history of EN; (b) tubular proteinuria $\left(\alpha_{1}\right.$-microglobulin $>10 \mathrm{mg} / \mathrm{l}$ or $>14$ $\mathrm{mg} / \mathrm{g}$ creatinine); (c) serum creatinine $>132.6 \mu \mathrm{mol} / \mathrm{l}$; (d) anemia (hemoglobin $<120 \mathrm{~g} / \mathrm{l}$ in males; $<113 \mathrm{~g} / \mathrm{l}$ in females), and (e) exclusion of other chronic kidney disease. The diagnosis of EN (diseased) was applied to individuals from EN villages who had any of the following combinations: $a+b+c+d+e$, or $b+c+d+e$, or $a+b+d+e$. Suspected of having EN were defined as $a+b+e$ or $\mathrm{b}+\mathrm{d}+\mathrm{e}$, and the ones at risk as healthy subjects who have been living in the households where some members were and/or have been diagnosed with EN $(a+e)$, while others as inhabitants of EN villages who did not fulfill any of the aforementioned criteria and who lived in non-EN households.

The study was approved by the Ethical Board of School of Medicine University of Zagreb, Croatian National Institute of Public Health and General Hospital 'Dr. Josip Benčević' Slavonski Brod, and all participants gave written informed consent.

\section{Methods}

The data collection, including epidemiological questionnaire, medical history and the clinical examination, was conducted in participants' homes by physicians and trained nurses. Weight and height were measured with participants standing without shoes and heavy outer garments. Body mass index (BMI) was calculated as weight divided by squared height $\left(\mathrm{kg} / \mathrm{m}^{2}\right)$. Blood pressure (BP) was measured during two visits, and each time three measurements were performed on the right arm by standard mercury sphygmomanometers with appropriate-sized cuffs (standard and large) in the sitting position after at least $5 \mathrm{~min}$ rest following ESH/ECS guidelines [25]. The mean value of the measurements was calculated.

Hypertension was defined as a BP $\geq 140 / 90 \mathrm{~mm} \mathrm{Hg}$, and/or current use of antihypertensive drugs. Treatment of hypertension was defined as usage of antihypertensive medication at the time of the interview. Control of hypertension was defined as pharmacological antihypertensive treatment associated with an average $\mathrm{BP}<140 / 90 \mathrm{~mm} \mathrm{Hg}$ at the time of the interview. Low income was defined as monthly income less than EUR 400, while low educa- 


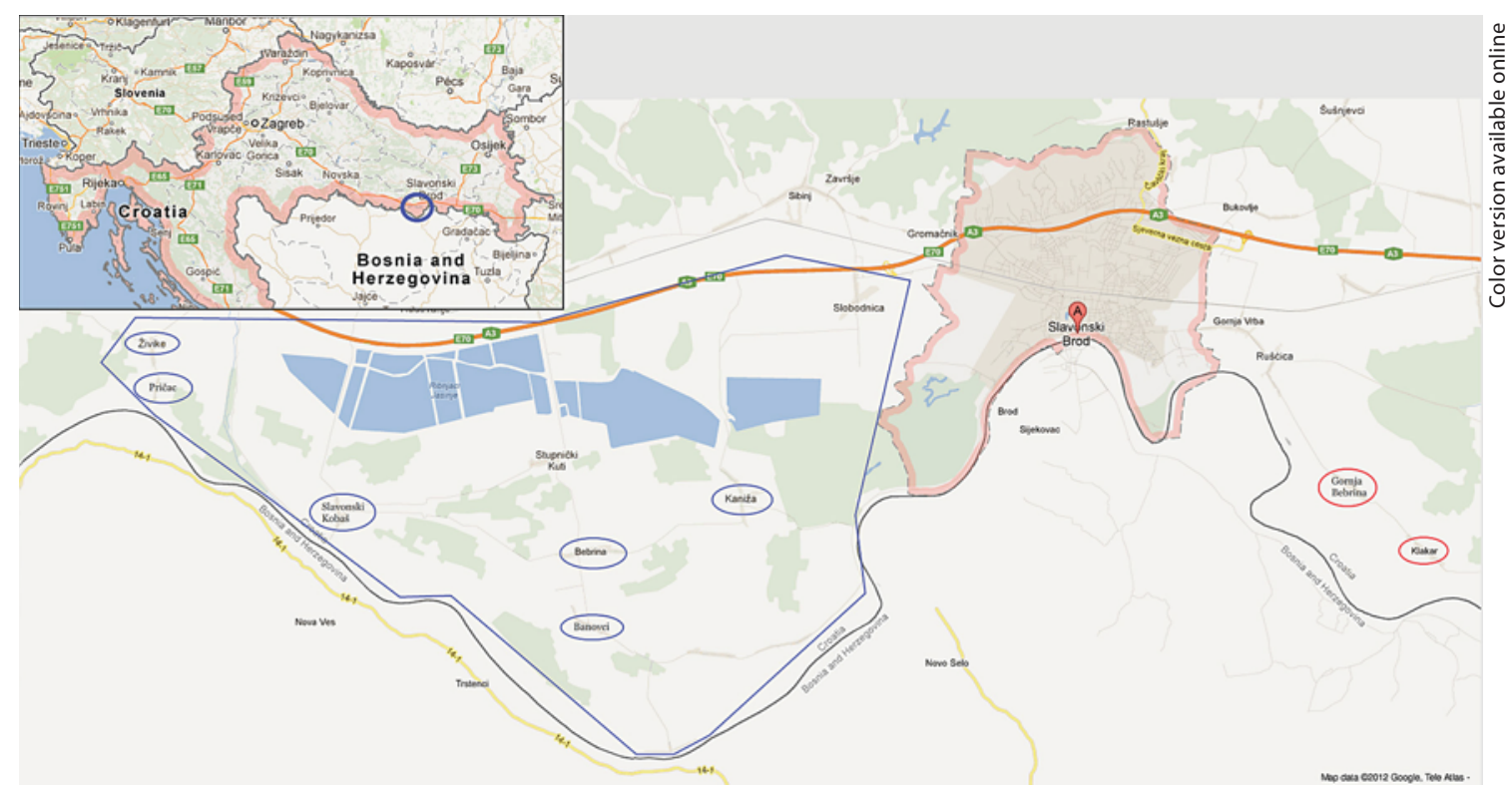

Fig. 1. Croatian endemic area with six endemic (blue circles) and two control (red circles) villages. From Google Maps/Google Earth; http://maps.google.hr; accessed on March 10, 2012.

tional level as 8 years of schooling or less. Laboratory analyses involved determination of hemoglobin, serum creatinine, urinary $\alpha_{1}$-microglobulin, albumin and creatinine from untimed spot urine sample. After being centrifuged, all blood and urine samples were stored at $4^{\circ} \mathrm{C}$, and on the same day transferred to Zagreb and analyzed in the Laboratory for Clinical Diagnostics University Hospital Center Zagreb. Hemoglobin was determined using optical fluid cytometry with the electronic counter ADVIA 2120 (Siemens, Deerfield, Ill., USA), serum creatinine using the Olympus AU 2700 machine with continuous photometric method with alkaline Picrat, and urinary $\alpha_{1}$-microglobulin and albumin by Siemens Dade Behring BN II Nephelometer. Kidney function was assessed by estimation of the glomerular filtration rate (GFR) using MDRD abbreviated formula: eGFR ( $\mathrm{ml} / \mathrm{min} /$ $\left.1.73 \mathrm{~m}^{2}\right)=186.3 \times\left(\right.$ serum creatinine $\left.{ }^{-1.154}\right) \times\left(\right.$ age $\left.^{-0.203}\right) \times(0.742$ if female).

Statistical analysis was performed using the Statistica 9 software (STATSOFT Inc., Tulsa, Okla., USA). Numerical variables were tested for the normality of distribution using the Kolmogorov-Smirnov test. Preliminary analyses were performed to ensure no violation of the assumptions of normality, linearity and homoscedasticity. Categorical data were expressed as numbers and frequencies. The differences between the groups were analyzed using Pearson's $\chi^{2}$ and $\chi^{2}$ for post-hoc analysis. Normally distributed variables were presented as means \pm standard deviations, and Student's $t$ test for independent samples was used for comparisons between two groups, while ANOVA for more than 2 groups, using Tukey's or Hochberg's test for post-hoc analysis. Data that were not normally distributed were presented as medians, and Kruskal-Wallis test was used to explore the differences between more than 2 groups. The Mann-Whitney U test was used for post-hoc analysis and to evaluate the statistical significance of differences between two groups. Standard multiple linear regression was used to explore the influence of different variables on hypertension. A p value $<0.05$ (two-sided tests) was considered significant.

\section{Results}

\section{Demographic Characteristics}

Data obtained from the study population are summarized in tables 1 and 2 . In the entire study population, there was no difference in BMI $(p=0.174)$ or age $(p=0.18)$ between men and women. Moreover, there was no difference between EN and control villages in gender distribution $(\mathrm{p}=0.754)$. Inhabitants in control villages were older $(p=0.005)$ and had higher BMI $(p=0.046)$ than the EN ones. Women in control villages had higher BMI than EN ones $(27.63 \pm 6.02$ vs. $26.4 \pm 5.35, \mathrm{t}=3.045, \mathrm{p}=0.002)$ and were older $(50.14 \pm 17.32$ vs. $47.86 \pm 17.36, t=1.994$; $\mathrm{p}=0.015)$. We failed to find any difference in blood pressure values between control and EN villages [systolic BP (SBP) $148.26 \pm 28.74$ vs. 145.43 vs. 26.08 , $\mathrm{p}=0.095$; diastolic BP (DBP) $85.04 \pm 12.89$ vs. $85.24 \pm 12.84, \mathrm{p}=$ $0.795]$. Moreover, in all villages no gender differences in 
Table 1. Demographic and laboratory characteristics of the study population (mean $\pm \mathrm{SD})$

\begin{tabular}{lccrl}
\hline & $\begin{array}{l}\text { Control } \\
\text { villages }\end{array}$ & \multicolumn{1}{l}{$\begin{array}{l}\text { Endemic } \\
\text { villages }\end{array}$} & $\mathrm{t}$ & $\mathrm{p}$ \\
\hline Males/females & $145 / 211$ & $496 / 750$ & $0.098^{*}$ & 0.754 \\
Age, years & $53.71 \pm 17.24$ & $50.87 \pm 16.94$ & 2.781 & 0.005 \\
SBP, mm Hg & $148.26 \pm 28.74$ & $145.43 \pm 26.08$ & 1.673 & 0.095 \\
DBP, mm Hg & $85.04 \pm 12.89$ & $85.24 \pm 12.84$ & -0.259 & 0.795 \\
Hypertensives & 158 & 633 & & \\
BMI & $27.65 \pm 5.35$ & $27.01 \pm 5.04$ & 1.993 & 0.046 \\
Hbg, g/l & $136.93 \pm 14.30$ & $136.13 \pm 15.33$ & 0.880 & 0.379 \\
Cr $(\mathrm{s}), \mu \mathrm{mol} / \mathrm{l}$ & $84.66 \pm 53.63$ & $93.07 \pm 73.65$ & -2.386 & 0.017 \\
eGFR, ml/min/ & & & & \\
\multicolumn{1}{c}{$1.73 \mathrm{~m}{ }^{2}$} & $71.74 \pm 16.70$ & $69.49 \pm 19.17$ & 2.002 & 0.045 \\
& & & &
\end{tabular}

Independent sample $\mathrm{t}$ test; ${ }^{*} \chi^{2}$ test.

$\mathrm{Hbg}=$ Hemoglobin; $\mathrm{Cr}(\mathrm{s})=$ serum creatinine.

SBP and DBP were observed (EN villages, SBP women vs. men, $145.76 \pm 27.63$ vs. $144.94 \pm 23.5 \mathrm{~mm} \mathrm{Hg}, \mathrm{t}=0.562$, $\mathrm{p}=0.574$; DBP $85.05 \pm 13.02$ vs. $85.53 \pm 12.58, \mathrm{t}=$ $-0.639, \mathrm{p}=0.523$; control villages, SBP $149.3 \pm 32.57$ vs. $146.76 \pm 22.02, \mathrm{t}=0.878, \mathrm{p}=0.381 ; \mathrm{DBP} 84.52 \pm 12.71$ vs. $85.8 \pm 13.15, \mathrm{t}=-0.92, \mathrm{p}=0.358)$. The frequency of hypertension positively correlated with age $(r=0.487)$, income less than EUR $400(\mathrm{r}=0.123)$, low level of education $(r=0.258)$ and BMI $(r=0.268)$, all being statistically significant (all $\mathrm{p}<0.001$ ), while it correlated negatively with eGFR $(\mathrm{r}=-0.313, \mathrm{p}<0.001)$.

The overall prevalence of hypertension in EN villages was significantly higher than in control villages $(\mathrm{p}=$ 0.005 ; table 3 ). In the control villages, the prevalence of hypertension was higher in men than in women ( $\mathrm{p}=$ 0.045), while in EN villages this difference was not statistically significant. Comparing the obtained data in EN with control villages, we failed to find any difference in overall treatment, control of all hypertensives and treated hypertensives (table 3 ). In both villages, women were treated more than men (EN villages 41.6 vs. $28.4 \%, \chi^{2}=$ $21.918, \mathrm{p}<0.001$; control villages 46.4 vs. $27.3 \%, \chi^{2}=$ $12.941, \mathrm{p}<0.001$ ), but significantly better control of treated hypertensives was achieved in men (EN villages 24.7 vs. $17.4 \%, \chi^{2}=9.386, p=0.002$; control villages 29.6 vs. $15.5 \%, \chi^{2}=9.387, \mathrm{p}=0.002$ ). The prevalence of hypertension was significantly higher in EN women when compared to the controls ( 49.7 vs. $42.1 \%, \mathrm{p}=0.014$ ), while no difference in the treatment and control of hypertension was found between them (table 3).

Hypertension in an Endemic Nephropathy Area
Analyzing differences among EN subgroups as well as between each EN subgroup and control group, we failed to find differences in BMI (table 2). Diseased and suspected of having EN were older and had higher SBP values than the other two EN subgroups as well as the control group $(\mathrm{p}<0.01)$. No difference in BP values was found between diseased and suspected of having EN ( $p>$ 0.05 ). Diseased had the highest relative risk of hypertension, being 1.85 -fold higher than in the control group (95\% CI 1.58-2.16, $\mathrm{z}=7.848, \mathrm{p}<0.001)$. Moreover, a higher risk for hypertension was also observed in suspected of having EN [RR $1.56(95 \%$ CI 1.33-1.84) z = 2.441, $\mathrm{p}=$ 0.015 ] and those at risk for EN [RR 1.17 (95\% CI 1.03-1.32) $\mathrm{z}=0.248, \mathrm{p}=0.804]$. There was no difference in hypertension prevalence between diseased and suspected of having EN (86 vs. $72.7 \%, \chi^{2}=1.937, \mathrm{p}=0.164$; table 4 ). We failed to find any difference in sex $(\mathrm{p}=0.094), \mathrm{BMI}(\mathrm{p}=$ $0.998)$, income $(\mathrm{p}=0.645)$ and the level of education $(\mathrm{p}=$ 0.053 ) between them. Furthermore, the prevalence of hypertension was higher in those at risk for EN when compared to the others, inhabitants completely unrelated to EN (54.3 vs. $45.8 \%, \chi^{2}=7.004, p=0.008$ ). In EN subgroups, women were treated more than men, but significant difference was only found in the suspected of having EN (20.6 vs. $\left.46.7 \%, \chi^{2}=4.584, p=0.032\right)$ and others $(27.4$ vs. $\left.40.3 \%, \chi^{2}=11.867, \mathrm{p}<0.001\right)$, while the difference of those at risk for EN was close to being significant $\left(\chi^{2}=\right.$ $3.61, p=0.057)$. However, treated men achieved better BP control than treated women (all $\mathrm{p}<0.05$; table 4 ).

Standard multiple linear regression showed that age and BMI $(\mathrm{p}<0.001)$ had significant influence on hypertension (table 5).

\section{Socioeconomic Findings}

There was no significant difference between EN and control villages either in the overall frequency of low income (68.65 vs. $\left.64.66 \% ; \chi^{2}=2.24, p=0.135\right)$, or in the low education level (59.77 vs. $\left.62.46 \%, \chi^{2}=0.583, p=0.445\right)$. In all villages, women had higher frequency of low education when compared to men (67.6 vs. $48.9 \%, \chi^{2}=46.224$, $\mathrm{p}<0.001)$ and higher frequency of low income (73.4 vs. $\left.61.8 \%, \chi^{2}=17.794, \mathrm{p}<0.001\right)$. In EN villages, women had lower mean of years of education than men $(7.4 \pm 3.35$ vs. $8.57 \pm 3.87, \mathrm{t}=-2.683, \mathrm{p}=0.008)$ and more frequently earned less than EUR 400 ( 71.9 vs. $61.8 \%, \chi^{2}=12.98$, $\mathrm{p}<0.001)$. Moreover, women in EN villages earned less than the controls (EN 71.9 vs. control $64 \%, \chi^{2}=4.657$, $\mathrm{p}=0.031$.

In all villages, less educated inhabitants and those who earned less had higher relative risk for hypertension [1.48

Kidney Blood Press Res 2012;35:678-686 
Table 2. Demographic and laboratory characteristics of included subgroups

\begin{tabular}{|c|c|c|c|c|c|c|c|c|c|}
\hline & & $\begin{array}{l}\text { Control villages } \\
(\mathrm{n}=356)\end{array}$ & $\begin{array}{l}\text { Diseased } \\
(\mathrm{n}=40)\end{array}$ & $\begin{array}{l}\text { Suspected } \\
(\mathrm{n}=76)\end{array}$ & $\begin{array}{l}\text { At risk } \\
(\mathrm{n}=385)\end{array}$ & $\begin{array}{l}\text { Others } \\
(\mathrm{n}=745)\end{array}$ & $\begin{array}{l}\text { Total } \\
(\mathrm{n}=1,602)\end{array}$ & $\mathrm{F}$ & $\mathrm{p}$ \\
\hline \multirow[t]{2}{*}{ Sex } & $\mathrm{F}$ & 211 & 25 & 35 & 244 & 446 & 961 & \multirow{2}{*}{$8.177^{*}$} & \multirow{2}{*}{0.085} \\
\hline & M & 145 & 15 & 41 & 141 & 299 & 641 & & \\
\hline \multirow[t]{2}{*}{ Age, years } & Mean & 53.71 & 72.78 & 61.54 & 48.26 & 49.95 & 51.50 & \multirow{2}{*}{30.840} & \multirow{2}{*}{$<0.001$} \\
\hline & $\mathrm{SD}$ & 17.24 & 6.44 & 15.69 & 15.29 & 17.05 & 17.04 & & \\
\hline \multirow[t]{2}{*}{$\mathrm{SBP}, \mathrm{mm} \mathrm{Hg}$} & Mean & 148.26 & 163.23 & 160.20 & 144.57 & 143.42 & 146.06 & \multirow{2}{*}{12.537} & \multirow{2}{*}{$<0.001$} \\
\hline & SD & 28.74 & 27.21 & 28.36 & 23.64 & 26.19 & 26.71 & & \\
\hline \multirow[t]{2}{*}{ DBP, mm Hg } & Mean & 85.04 & 85.38 & 90.13 & 85.92 & 84.38 & 85.20 & \multirow{2}{*}{3.899} & \multirow{2}{*}{0.004} \\
\hline & $\mathrm{SD}$ & 12.89 & 13.96 & 15.21 & 12.16 & 12.76 & 12.85 & & \\
\hline Hypertensives & & 158 & 34 & 55 & 207 & 341 & 795 & & \\
\hline \multirow[t]{2}{*}{ BMI } & Mean & 27.65 & 26.80 & 26.79 & 27.51 & 26.78 & 27.15 & \multirow{2}{*}{2.268} & \multirow{2}{*}{0.060} \\
\hline & $\mathrm{SD}$ & 5.35 & 5.25 & 4.85 & 5.10 & 5.01 & 5.11 & & \\
\hline \multirow[t]{2}{*}{$\mathrm{Hbg}, \mathrm{g} / \mathrm{l}$} & Mean & 136.93 & 95.36 & 136.07 & 137.02 & 137.87 & 136.31 & \multirow{2}{*}{93.319} & \multirow{2}{*}{$<0.001$} \\
\hline & SD & 14.30 & 13.63 & 18.96 & 12.24 & 13.31 & 15.11 & & \\
\hline \multirow[t]{2}{*}{$\mathrm{Cr}(\mathrm{s}), \mu \mathrm{mol} / \mathrm{l}$} & Mean & 84.66 & 379.45 & 103.84 & 82.27 & 82.18 & 91.20 & \multirow{2}{*}{315.813} & \multirow{2}{*}{$<0.001$} \\
\hline & $\mathrm{SD}$ & 53.63 & 271.29 & 49.88 & 14.28 & 16.21 & 69.77 & & \\
\hline \multirow[t]{2}{*}{$\mathrm{eGFR}, \mathrm{ml} / \mathrm{min} / 1.73 \mathrm{~m}^{2}$} & Mean & 71.74 & 19.69 & 56.38 & 71.84 & 72.29 & 69.99 & \multirow{2}{*}{111.247} & \multirow{2}{*}{$<0.001$} \\
\hline & SD & 16.70 & 15.60 & 15.78 & 15.16 & 17.23 & 18.67 & & \\
\hline \multirow{2}{*}{$\alpha_{1}$-Microglobulin (u), mg/l } & Median & 5.37 & 79.3 & 16.15 & 5.18 & 5.18 & 5.18 & \multirow{2}{*}{$324.015^{\dagger}$} & \multirow{2}{*}{$<0.001$} \\
\hline & Range & 5-119 & $10.2-398$ & $10.1-91.8$ & $2.2-23$ & $2.25-133$ & $2.2-398$ & & \\
\hline \multirow[t]{2}{*}{ Albumin (u), mg/l } & Median & 5.78 & 56.2 & 16.35 & 5.47 & 6.12 & 6.31 & \multirow{2}{*}{$135.561^{\dagger}$} & \multirow{2}{*}{$<0.001$} \\
\hline & Range & $2-300$ & $3.7-700$ & $2.59-208$ & $2-342$ & $2-482$ & $2-700$ & & \\
\hline
\end{tabular}

ANOVA, Hochberg's test for post-hoc analysis; ${ }^{*}$ Pearson's $\chi^{2}$ test and $\chi^{2}$ for post-hoc analysis, ${ }^{\dagger}$ Kruskal-Wallis test, post-hoc analysis using Mann-Whitney U test.

(95\% CI 1.35-1.62, $\mathrm{z}=8.517, \mathrm{p}<0.001)$ and $1.23(95 \% \mathrm{CI}$ $1.12-1.62, \mathrm{z}=4.327, \mathrm{p}<0.001)$, respectively]. The same was observed in EN and control villages separately.

\section{Discussion}

Hypertension was not considered to be a characteristic of EN, and was only described in the advanced phase of this peculiar chronic kidney disease $[1,3,5,6]$. Even though many earlier reports on EN observed normal blood pressure to be a characteristic, several recent studies have reported higher prevalence of hypertension even in EN offspring $[10,26,27]$. Still, in the last few decades no consistent data on hypertension have been reported with the prevalence ranging from 15 to $59 \%[6,9,28]$. In the aforementioned studies, all data and results on hypertension prevalence in EN were obtained in small groups, while a systematic epidemiologic survey with a large cohort has never been performed. Thus, our study is the first comprehensive report on hypertension prevalence, treatment and control in one EN area.

In this study, we analyzed data obtained in 1,602 adult inhabitants from six EN and two control villages in the Croatian rural area. EN is, at least early in its clinical course, a salt-wasting nephropathy. Thus, we expected the prevalence of hypertension to be lower in EN villages than in controls, particularly in those who might be considered to be in the early phase of the disease, i.e. suspected of having EN. This speculation was supported not only by the results from older reports obtained in different EN areas $[1,3,11]$, but also by the fact that hypertension has never been reported to be a clinical feature of aristolochic acid nephropathy, firstly named Chinese herbs nephropathy $[15,16]$. 
Table 3. Prevalence, treatment and control of hypertension in EN and control villages

\begin{tabular}{|c|c|c|c|c|}
\hline & $\begin{array}{l}\text { EN } \\
\text { villages }\end{array}$ & $\begin{array}{l}\text { Control } \\
\text { villages }\end{array}$ & $\chi^{2}$ & $\mathrm{p}$ \\
\hline \multicolumn{5}{|c|}{ Prevalence, $\%$} \\
\hline Total & 50.8 & 46.5 & 1.879 & 0.005 \\
\hline Male & 52.6 & $53.5^{*}$ & 0.058 & 0.811 \\
\hline Female & 49.7 & 42.1 & 6.107 & 0.014 \\
\hline \multicolumn{5}{|c|}{ Treatment, \% } \\
\hline Total & 36.2 & 37.9 & 0.276 & 0.6 \\
\hline Male & $28.4^{*}$ & $27.3^{*}$ & 0.116 & 0.734 \\
\hline Female & 41.6 & 46.4 & 2.415 & 0.12 \\
\hline \multicolumn{5}{|c|}{ Control of all hypertensives, $\%$} \\
\hline Total & 7.1 & 7.6 & 0.042 & 0.837 \\
\hline Male & 7 & 8.1 & 0.348 & 0.555 \\
\hline Female & 7.2 & 7.2 & 0.014 & 0.908 \\
\hline \multicolumn{5}{|c|}{ Control of treated hypertensives, $\%$} \\
\hline Total & 19.7 & 20 & 0.002 & 0.96 \\
\hline Male & $24.7^{*}$ & $29.6^{*}$ & 3.222 & 0.073 \\
\hline Female & 17.4 & 15.5 & 0.581 & 0.446 \\
\hline
\end{tabular}

Values are expressed as percentages. $\chi^{2}$ test was used to compare the differences in prevalence, treatment and control of hypertension between EN and control villages.

${ }^{*} \mathrm{p}<0.05$ for differences between men and women.

Surprisingly, and in contrast to the previous observations on lower prevalence of hypertension, we found higher than expected prevalence in endemic villages, and the observed shift to older ages in several EN areas, including the one in Croatia, could be one of the explanations for this finding $[2,5,6,9,12,13]$. Similar to the majority of epidemiological surveys worldwide, in the present study age had a high influence on hypertension. In addition, significant improvement in farming practices with the changes in the microenvironment and lifestyle in the EN area prevented further chronic dietary exposure to nephrotoxic aristolochic acid, the etiologic agent of EN, and thereby decreased the incidence of new cases of salt-wasting nephropathy in the early phase of EN [21, 29].

In the present study, we found the prevalence of hypertension was higher in EN than in control villages. Interestingly, the prevalence of hypertension (37.6\%) in this rural continental region of Croatia was higher than the prevalence found in other rural parts of Croatia [30]. In this rural area, the higher prevalence of hypertension positively correlated with age, BMI, low income and level of education, and negatively with eGFR. Those with a low level of education and poor income had the highest risk
Table 4. Prevalence, treatment and control of hypertension in EN village subgroups

\begin{tabular}{|c|c|c|c|c|c|c|}
\hline & $\begin{array}{l}\text { Diseased } \\
\text { (a) }\end{array}$ & $\begin{array}{l}\text { Suspected } \\
\text { (b) }\end{array}$ & $\begin{array}{l}\text { At risk } \\
\text { (c) }\end{array}$ & $\begin{array}{l}\text { Others } \\
\text { (d) }\end{array}$ & $\begin{array}{l}\text { Pearson's } \\
\chi^{2}\end{array}$ & $\mathrm{p}$ \\
\hline \multicolumn{7}{|c|}{ Prevalence, \% } \\
\hline Total & 86.0 & 72.7 & 54.3 & 45.8 & 51.013 & $<0.001$ \\
\hline Male & 87.5 & 70.8 & 58.4 & 46.6 & 22.594 & $<0.001$ \\
\hline Female & 85.2 & 75 & 52 & 45.3 & 29.341 & $<0.001$ \\
\hline \multicolumn{7}{|c|}{ Treatment, \% } \\
\hline Total & 56.8 & 32.8 & 36.2 & 35.0 & 7.36 & 0.061 \\
\hline Male & 50.0 & $20.6^{*}$ & 29.8 & $27.4^{*}$ & 4.437 & 0.218 \\
\hline Female & 60.9 & 46.7 & 40.1 & 40.3 & 4.181 & 0.243 \\
\hline \multicolumn{7}{|c|}{ Control of all hypertensives, $\%$} \\
\hline Total & 0 & 4.7 & 6.6 & 8.3 & 4.53 & 0.21 \\
\hline Male & 0 & 2.9 & 7.7 & 7.9 & 2.219 & 0.528 \\
\hline Female & 0 & 6.7 & 6 & 8.6 & 3.007 & 0.391 \\
\hline \multicolumn{7}{|c|}{ Control of treated hypertensives, \% } \\
\hline Total & 0 & 14.3 & 18.4 & 23.8 & 7.367 & 0.061 \\
\hline Male & 0 & 14.3 & $25.8^{*}$ & $28.8^{*}$ & 3.202 & 0.362 \\
\hline Female & 0 & 14.3 & 14.9 & 21.4 & 4.596 & 0.204 \\
\hline
\end{tabular}

Differences in prevalence, treatment and control of hypertension between EN subgroups (diseased, suspected, at risk and others) were analyzed by Pearson's $\chi^{2}$ test, and $\chi^{2}$ for post-hoc analysis. ${ }^{*} \mathrm{p}<0.05$ for differences between men and women.

Table 5. Standard multiple linear regression - the influence of different variables on hypertension

\begin{tabular}{lrrrr}
\hline & B & SE B & $\beta$ & \multicolumn{1}{c}{$p$} \\
\hline STEP 1 & & & & \\
$\quad$ Constant & -0.020 & 0.042 & & 0.628 \\
$\quad$ Age & 0.013 & 0.001 & 0.473 & $<0.001$ \\
STEP 2 & & & & \\
$\quad$ Constant & -0.360 & 0.073 & & $<0.001$ \\
$\quad$ Age & 0.013 & 0.001 & 0.461 & $<0.001$ \\
BMI & 0.014 & 0.002 & 0.155 & $<0.001$ \\
Income <EUR 400 & -0.049 & 0.028 & -0.049 & 0.082 \\
& & & &
\end{tabular}

$\mathrm{R}^{2}=0.223, \Delta \mathrm{R}^{2}=0.025 ; \mathrm{p}<0.001$.

for hypertension. Even though the subjects in control villages had higher BMI and were older than in EN ones, hypertension was less prevalent. Inhabitants in EN villages were less educated and earned less than controls, what could additionally explain their higher prevalence of hypertension. In the recent review, Grotto et al. [31] have presented how low socioeconomic status, i.e. occupation in low ranking workers, low level of education and 
low income, was associated with higher blood pressure. Moreover, the results of recent studies on hypertension confirmed the association of lower monthly income and the level of education with higher blood pressure, lower awareness and control of hypertension [32-35]. The greater prevalence of hypertension was also observed in other rural parts of Croatia and Romania [29, 36], while the prevalence was lower in Spain [37]. In the Greek epidemiology survey, the prevalence of hypertension was higher in rural areas and among individuals of lower education [38]. The aforementioned data emphasize the importance of modifiable socioeconomic factors in the development of hypertension. Of note is that higher prevalence of renal impairment in EN villages, i.e. decreased values of eGFR and higher values of albuminuria and $\alpha_{1}$ microglobulinuria could have contributed to the observed higher prevalence of hypertension in the EN area as well.

In this study, hypertension was highly prevalent in diseased, i.e. inhabitants of EN villages in advanced stages of chronic kidney disease. Interestingly, we failed to find any difference in hypertension prevalence between diseased and suspected of having EN who might be considered as subjects in an early phase of disease. Moreover, the prevalence of hypertension was significantly higher in diseased and suspected of having EN than in other two EN subgroups. Bukvić et al. [9] observed the same differences in the subgroups in Kolubara region in Serbia. It seems that nowadays hypertension is frequently present in all EN subgroups. Thus, hypertension could not only be a characteristic of the advanced, but also of earlier phases of EN. Changes in lifestyle, obesity and more stress as a result of poor socioeconomic status seem to contribute more significantly to earlier manifestation of hypertension and thus very likely overcome salt wasting present in the early phase of this chronic tubulointerstitial nephropathy. We found that hypertension in the control villages was more prevalent in men than in women, while in the EN ones no gender difference in prevalence was observed. Interestingly, in Greece the prevalence was greater in the rural population and significantly higher among the men aged $<55$ years, but slightly higher among women aged $>55$ years [38]. In contrast, in Turkey, hypertension was more prevalent in women despite no urbanrural difference in hypertension prevalence for every age group [39]. In a Czech rural population, Cifkova et al. [40] reported on significantly higher prevalence in men than in women due to greater prevalence of obesity among men. Pimenta et al. [41] reported higher prevalence of hypertension among men than women in a rural area in
Brazil despite women being more obese. The observed gender differences in the prevalence of hypertension reflect the complex influences of different hypertension risk factors in culturally and ethnically different rural areas. In both EN and control villages, more women were treated than men, but better control was achieved in men. Despite no gender difference in BMI and age in the entire study population, the observed poorer control among treated female hypertensives could be explained by their lower monthly income and lower level of education. Moreover, higher prevalence of hypertension and poorer control in EN women compared to women from control villages who were older and more frequently overweight could again be explained by their lower socioeconomic status.

In the present study, the socioeconomic status significantly influenced the prevalence, treatment and control of hypertension in an EN area, particularly in women.

\section{Limitations}

Our study has several limitations. First, in the study the reported prevalence of hypertension in the Croatian $\mathrm{EN}$ area is for overall nonpregnant, noninstitutionalized, nonmilitary population with no other clinically proven kidney diseases except EN. Thus, we could not exclude a potential underestimation bias of hypertension. However, the same rule was applied for both EN and control villages. Moreover, the potential underestimation bias may also lie in the definition of hypertension, which does not include adult inhabitants with successfully controlled hypertension by nonpharmacological means. Nevertheless, this number is very probably too small to have any significant influence on the final result and conclusion. Second, the design of our study is a cross-sectional one, and therefore makes it difficult to analyze the trends of hypertension characteristics over time. Third, in our study we did not analyze health care system factors such as health care coverage which can influence treatment and control of hypertension in this EN area. However, this probably has limited influence since all Croatian citizens have mandatory basic health insurance.

\section{Conclusion}

The prevalence of hypertension is high in the Croatian endemic rural area. Hypertension is not only a clinical feature of the advanced phase of EN, but also of all EN subgroups. Low income and level of education, besides renal impairment and BMI, are important risk factors for 
hypertension in endemic villages. Low socioeconomic status is a strong risk factor for hypertension and contributes not only to higher prevalence, but also to poorer control of hypertension, especially in women from EN villages. A few decades ago, villagers from the endemic area were more frequently exposed to aristolochic acid which damaged proximal tubule and destroyed macula densa, thereby causing salt-wasting nephropathy and late development of hypertension. With advances in agriculture, exposure to this nephrotoxin diminished and disappeared resulting in the reduction of salt wasting. Nowadays, changes in lifestyle, obesity and more stress as a result of poor socioeconomic status in this rural area significantly contribute to a higher prevalence of hypertension. The evolution of changes in hypertension in EN is a good example and a good lesson of how important environmental factors are for development of hypertension.

\section{Acknowledgements}

This study was funded by grants from Ministry of Science, Education and Sport, Republic of Croatia (No. 0108109 and No. 108-0000000-0329 to B. Jelaković). The work was also supported by Abbott Laboratories, Representative for Republic of Croatia and local grants of the Public Health Institute Slavonski Brod (A. Cvitković) and General Hospital Slavonski Brod (M. Bitunjac). The authors particularly wish to thank the inhabitants of EN and control villages who participated in this study for their cooperation, as well as nurses, technicians and non-medical coworkers for their assistance in the field work.

\section{References}

1 Radovanović Z: Epidemiology and etiology of endemic nephropathy; in Radovanović Z, Sinđić M, Polenaković M, Djukanović Lj, Petronić V (eds): Endemic Nephropathy. Belgrade, Zavod za udžbenike i nastavna sredstva, 2002, pp 22-135.

-2 Čvorišćec D, Čeović S, Boršo G, Rukavina AS: Endemic nephropathy in Croatia. Clin Chem Lab Med 1998;36:271-277.

-3 Radonić M, Radošević Z: Clinical features of Balkan endemic nephropathy. Food Chem Toxicol 1992;30:189-192.

4 Stefanović V, Toncheva D, Atanasova S, Polenaković M: Etiology of Balkan endemic nephropathy and associated urothelial cancer. Am J Nephrol 2006;26:1-11.

5 Miletić-Medved M, Domijan A-M, Peraica M: Recent data on endemic nephropathy and related urothelial tumors in Croatia. Wien Klin Wochenschr 2005;117:604-609.

6 Čeović S, Miletić-Medved M: Epidemiological features of endemic nephropathy in focal area of Brodska Posavina, Croatia; in Čvorišćec D, Čeović S, Stavljenić-Rukavina A (eds): Endemic nephropathy in Croatia. Zagreb, Academia Croatica scientiarum medicarum, 1996, pp 7-21.

7 Croatian population census 2001 charts. http://www.dzs.hr/default_e.htm, accessed on 28 September 2011.

$\$ 8$ Batuman V: Fifty years of Balkan endemic nephropathy. Daunting questions, elusive answers. Kidney Int 2006;69:644-646.
-9 Bukvić D, Marić I, Arsenović A, Janković S, Djukanović LJ: Prevalence of Balkan endemic nephropathy has not changed since 1971 in the Kolubara region in Serbia. Kidney Blood Press Res 2007;30:117-123.

10 Dimitrov PS, Simeonov VA, Stein AD: Balkan endemic nephropathy in Vratza, Bulgaria, 1964-1987: an epidemiologic analysis of population-based disease registers. Eur J Epidemiol 2001;17:847-853.

$\checkmark 11$ Miletić Medved M, Jelaković B, Bistrović D, Leko N, Marić Z: Epidemiological characteristics of endemic nephropathy in Croatia in 2005. Acta Med Croat 2007;61:141-148.

12 Čeović S, Hrabar A, Radonić M, Stavljenić A, Čvoriščec D, Pleština R, et al: Epidemiological and social medical characteristics of Balkan endemic nephropathy in Brod-Posavina focus of Brodska Posavina. Med Vjes 1988; 20:53-57.

13 Stasević Z, Subarić-Gorgieva G, Krcmarević J, Stolić R, Trajković G: Results of kidney function measurement and blood pressure in population from endemic region of Vitina. Med Pregl 2008;61:400-403.

14 Cosyns JP: Aristolochic acid and 'Chinese herbs nephropathy'. A review of the evidence to date. Drug Saf 2003;26:33-48.

15 Notier JL, Vanherweghem JL: For patients taking herbal therapy - lessons from aristolochic acid nephropathy. Nephrol Dial Transplant 2007;22:1512-1517.

16 Debelle FD, Vanherweghem JL, Nortier JL: Aristolochic acid nephropathy: a worldwide problem. Kidney Int 2008;74:158-169.
17 Grollman AP, Scarborough J, Jelaković B: Aristolochic acid nephropathy: an environmental and iatrogenic disease. Adv Mol Tox 2009;3:211-227.

18 Grollman AP, Shibutani S, Moriya M, Miller F, Wu L, Moll U, et al: Aristolochic acid and the etiology of endemic (Balkan) nephropathy. Proc Natl Acad Sci 2007; 104:1212912134.

-19 Jelaković B, Karanović S, Vuković-Lela I, Miller F, Edwards KL, Nikolić J, et al: Aristolactam-DNA adducts are a biomarker of environmental exposure to aristolochic acid. Kidney Int 2012;81:559-567.

20 Cosyns JP, Jadoul M, Squifflet JP, De Plaen JF, Ferluga D, van Ypersele de Strihou C: Chinese herbs nephropathy: a clue to Balkan endemic nephropathy? Kidney Int 1994;45: 1680-1688.

21 Hranjec T, Kovač A, Kos J, Mao W, Chen JJ, Grollman AP, Jelaković B: The case for chronic poisoning by aristolochia. Croat Med J 2005;46:116-125.

22 Jonge H, Vanrenterghem Y: Aristolochic acid: common culprit of Chinese herbs nephropathy and Balkan endemic nephropathy. Nephrol Dial Transplant 2008;23:39-41.

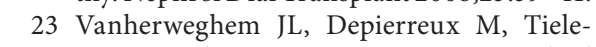
mans C, Abramowicz D, Dratwa M, Jadoul $\mathrm{M}$, et al: Rapidly progressive interstitial renal fibrosis in young women: association with slimming regimen including Chinese herbs. Lancet 1993;341:387-391. 
24 World Health Organization: Memorandum. The endemic nephropathy of South-Eastern Europe. Bull WHO 1965;32:441-448.

25 European Society of Hypertension-European Society of Cardiology Guidelines Committee: 2003 European Society of Hypertension-European Society of Cardiology guidelines for the management of arterial hypertension. J Hypertens 2003;21:10111053.

-26 Arsenović A, Bukvić D, Trbojević S, Maretić I, Djukanović LJ: Detection of renal dysfunctions in family members of patients with Balkan endemic nephropathy. Am J Nephrol 2005;25:50-54.

-27 Dimitrov P, Tsolova S, Georgieva R, Bozhilova D, Simeonov V, Bonev A, et al: Clinical markers in adult offspring of families with and without Balkan endemic nephropathy. Kidney Int 2006;69:723-729.

-28 Čukuranović R, Petrović B, Čukuranović Z, Stefanović V: Balkan endemic nephropathy: a decreasing incidence of the disease. Pathol Biol 2000;48:558-561.

-29 Cvitković A, Vuković Lela I, Edwards K, Karanović S, Jurić D, Čvoriščec D, Fuček M, Jelaković B: Could disappearance of endemic (Balkan) nephropathy be expected in forthcoming decades. Kidney Blood Press Res 2012;35:147-152.
30 Jelaković B, Kuzmanić D, Laganović M: Epidemiology of arterial hypertension in Croatia EH-UH 2000. Liječ Vijes 2001;123:334336.

31 Grotto I, Huerta M, Sharabi Y: Hypertension and socioeconomic status. Curr Opin Cardiol 2008;23:335-339.

32 Vitezić D, Burke T, Mršić-Pelčić J, Mavrić Z, Zaputović L, Zupan G, et al: Characteristics of blood pressure in treated hypertensive patients in Croatia. Blood Press Suppl 2005; 14 33-41.

33 Albert MA, Glynn RJ, Burning J, Ridker PM: Impact of traditional and novel risk factors on the relationship between socioeconomic status and incident of cardiovascular events. Circulation 2006;114:2619-2626.

34 Agymang C, van Valkengoed I, Koopmans R, Stronks K: Factors associated with hypertension, awareness, treatment and contro among ethnic groups in Amsterdam: The SUNSET study. J Hum Hypertens 2006;20: 874-881.

35 He J, Munter P, Chen J, Roccella EJ, Streiffer RH, Whelton PK: Factors associated with hypertension control in the general population of the United States. Arch Intern Med 2002;162:1051-1058.

36 Dorobantu M, Darabont RO, Badila E, Ghiorghe S: Prevalence, awareness, treatment, and control of hypertension in Romania: results of the SEPHAR Study. Int J Hypertens DOI: $\underline{10.4061 / 2010 / 970694}$
37 Perez-Fernandez R, Mariño AF, CadarsoSuarez C, Botana MA, Tome MA, Solache I, et al: Prevalence, awareness, treatment and control of hypertension in Galicia (Spain) and association with related diseases. J Hum Hypertens 2007;21:366-373.

>38 Psaltopoulou T, Orfanos P, Naska A, Lenas D, Trichopoulos D, Trichopoulou A: Prevalence, awareness, treatment and control of hypertension in a general population sample of 26913 adults in the Greek EPIC study. Int J Epidemiol 2004;33:1345-1352.

39 Altun B, Arici M, Nergizoğlu G, Derici Ü, Karatan O, Turgan Ç, et al: Prevalence, awareness, treatment and control of hypertension in Turkey (the Patent T study) in 2003. J Hypertens 2005;23:1817-1823.

40 Cifkova R, Škodova Z, Lánska V, Adámková V, Novozámska E, Petrižliková Z, et al: Trends in blood pressure levels, prevalence, awareness, treatment, and control of hypertension in the Czech population from 1985 to 2000/01. J Hypertens 2004;22:1479-1485.

41 Pimenta AM, Kac G, Gazzinelli A, CorreaOliveira R, Velásquez-Meléndez G: Association between central obesity, triglycerides and hypertension in a rural area in Brazil. Arq Bras Cardiol 2008;90:386-392. 